\title{
FAKTOR-FAKTOR YANG MEMPENGARUHI OPINI AUDIT GOING CONCERN
}

\section{(Studi Empiris pada Perusahaan Pertambangan yang Terdaftar di Bursa Efek Indonesia Periode 2015-2017) Suci Rahmadona ${ }^{1}$, Sukartini ${ }^{2}$ dan Dedy Djefris ${ }^{3}$}

\author{
1Jurusan Akuntansi, Politeknik Negeri Padang \\ Email: sucirahmadona6@gmail.com \\ 2 Jurusan Akuntansi, Politeknik Negeri Padang \\ Email: tiensukartini28@gmail.com \\ 3 Jurusan Akuntansi, Politeknik Negeri Padang \\ Email:dedy.djefris@gmail.com
}

\begin{abstract}
Going concern audit opinion is an opinion issued by the auditor to ascertain whether the company can maintain its survival. This research was conducted to examine the factors that influence the going concern audit opinion. These factors are, company size, company growth, solvency and previous year's audit opinion. The sample in this study are mining companies listed on the Indonesia Stock Exchange during the 2015-2017 period. The sample selection is done by purposive sampling technique, namely the selection of samples based on certain criteria. So that the total sample of this study was 60 samples. Data analysis used is logistic regression analysis using SPSS version 20. The results of this study are company size, company growth and solvency does not affect the going concern audit opinion. Whereas, the previous year's audit opinion affects the going-concern audit opinion.
\end{abstract}

Keywords: Going Concern Audit Opinion, Company Size, Company Growth, Solvability, and Previous Year Audit Opinion.

\section{ABSTRAK}

Opini audit going concern merupakan opini yang dikeluarkan auditor untuk memastikan apakah perusahaan dapat mempertahankan kelangsungan hidupnya (IAPI, 2011). Penelitian ini dilakukan untuk menguji faktor-faktor yang mempengaruhi opini audit going concern. Faktor-faktor tersebut yaitu, ukuran perusahaan, pertumbuhan perusahaan, solvabilitas, dan opini audit tahun sebelumnya. Sampel dalam penelitian ini adalah perusahaan pertambangan yang terdaftar di Bursa Efek Indonesia selama periode 2015-2017. Pemilihan sampel dilakukan dengan teknik purposive sampling, yaitu pemilihan sampel berdasarkan kriteria-kriteria tertentu. Sehingga diperoleh total sampel penelitian ini sebanyak 60 sampel. Analisis data yang digunakan adalah analisis regresi logistik menggunakan aplikasi SPSS versi 20. Hasil penelitian ini adalah ukuran perusahaan, pertumbuhan perusahaan dan solvabilitas tidak berpengaruh terhadap opini audit going concern. Sedangkan, variabel opini audit tahun sebelumnya berpengaruh terhadap opini audit going concern.

Kata kunci: Opini Audit Going Concern, Ukuran Perusahaan, Pertumbuhan Perusahaan, Solvabilitas dan Opini Audit Tahun Sebelumnya. 


\section{PENDAHULUAN}

Ikatan Akuntan Indonesia (IAI, 2015) mendefinisikan laporan keuangan sebagai struktur yang menyajikan posisi keuangan dan kinerja keuangan dalam sebuah entitas dengan tujuan memberikan informasi mengenai posisi keuangan, kinerja keuangan dan arus kas suatu entitas yang bermanfaat bagi pengguna laporan dalam pembuatan keputusan ekonomi. Laporan Keuangan merupakan bagian yang tidak dapat dipisahkan dari suatu perusahaan, karena laporan keuangan merupakan salah satu media utama yang dapat digunakan perusahaan untuk memberikan informasi keuangannya kepada pihak luar. Pihak-pihak yang berkepentingan atas laporan keuangan tersebut salah satunya adalah investor (IAI, 2015).

Menurut Siregar dan Rahman (2012) Investor menggunakan laporan keuangan sebagai dasar dalam pengambilan keputusan untuk berinvestasi, salah satu referensi yang digunakan investor untuk mengambil keputusan berkaitan dengan investasinya adalah opini perusahaan yang diberikan oleh auditor independen dalam laporan keuangan perusahaan. Dalam penelitian yang dilakukan oleh Setiawan dan Suryono (2015) menyatakan bahwa jika auditor tidak menemukan adanya ketidakpastian material terhadap kemampuan suatu perusahaan untuk mempertahankan kelangsungan usahanya, maka auditor akan memberikan opini audit non going concern. Namun sebaliknya, jika auditor menemukan adanya ketidakpastian material terhadap kemampuan suatu perusahaan untuk mempertahankan kelangsungan usahanya, maka auditor akan memberikan opini audit going concern. Opini audit going concern merupakan opini yang dikeluarkan auditor untuk memastikan apakah perusahaan dapat mempertahankan kelangsungan hidupnya (IAPI, 2011). Opini audit going concern sangat penting karena sangat berguna bagi para pemakai laporan keuangan untuk membuat keputusan investasi yang tepat dalam berinvestasi, karena ketika seorang investor akan melakukan investasi, investor perlu memahami kondisi keuangan perusahaan, terutama menyangkut tentang kelangsungan hidup perusahaan tersebut (Setiawan dan Suryono, 2015). Hal ini membuat auditor mempunyai tanggung jawab yang besar untuk mengeluarkan opini audit going concern yang sesuai dengan keadaan sesungguhnya. Dalam sebuah artikel yang diterbitkan oleh PricewaterhouseCoopers (2016), menyebutkan sebanyak 40 perusahaan pertambangan global mengalami kerugian terbesar sepanjang sejarah pada tahun 2015 dengan total kerugian sebesar 27 milliar dollar AS atau setara sekitar Rp 364,5 triliun pada kurs Rp 13.500 per dollar AS. Di tahun 2016, harga komoditas tambang pun kembali turun sebesar 25\% dibanding tahun 2015 (Gewati, 2016). Agar tetap bisa bertahan dan melanjutkan usahanya, perusahaan pertambangan berusaha meningkatkan produktifitas. Namun juga ada sebagian dari perusahaan pertambangan yang melepas aset atau menutup perusahaan demi mempertahankan kelangsungan usaha.

Hal tersebut tentunya juga berimbas pada perusahaan pertambangan di Indonesia. Tahun 2015 tidak ada perusahaan pertambangan di Indonesia dengan kapitalisasi pasar melebihi US\$4 miliar. Angka tersebut merupakan batas terendah agar dapat masuk dalam jajaran 40 perusahaan pertambangan terbesar di dunia 
berdasarkan kapitalisasi pasar. Perusahaan pertambangan di Indonesia pada saat itu selain berjuang mengatasi masalah lemahnya harga komoditi juga dihadapi masalah dengan menurunnya permintaan dari Tiongkok dan negara berkembang lainnya. Hal ini menyebabkan terjadinya penurunan yang signifikan pada kinerja keuangan perusahaan pertambangan di Indonesia. Kapitalisasi pasar secara keseluruhan untuk perusahaan pertambangan yang tercatat di Bursa Efek Indonesia turun dari Rp 255 triliun pada tanggal 31 Desember 2014 menjadi Rp 161 triliun pada tanggal 31 Desember 2015. Penurunan sebesar 37\% ini dipicu oleh jatuhnya harga komoditas.

Namun, pada tahun 2016 kapitalisasi pasar perusahaan pertambangan yang tercatat di Bursa Efek Indonesia meningkat sebesar 23\% dari penurunan tahun 2015 menjadi Rp198 triliun yang sejalan dengan kenaikan harga sejumlah komoditas dan perbaikan keyakinan investor terhadap sektor pertambangan Indonesia mengingat tindakan yang telah dilakukan untuk mengantisipasi dampak penurunan harga komoditas (PricewaterhouseCoopers, 2016). Pada tahun 2017, keadaan sektor pertambangan sudah mulai membaik, membaiknya kondisi pertambangan di Indonesia tergambar dari mulai banyaknya perusahaan pertambangan yang kembali beroperasi serta adanya peningkatan produksi. Penigkatan Sektor pertambangan ini tidak terlepas dari harga komoditi tambang dunia yang mulai membaik, selain itu pemerintah juga mengeluarkan standarisasi harga acuan yang dinilai cukup membantu (Beawiharta, 2017). Hal ini menjadi alasan mengapa sektor pertambangan dijadikan sampel dalam penelitian ini, karena di tahun 2015 kapitalisasi pasar turun atau anjlok sehingga mendorong perusahaan tambang harus berupaya keras meningkatkan produktifitas, ditambah dengan adanya perusahaan yang melakukan pelepasan aset, ini tentunya akan berpengaruh terhadap going concern suatu perusahaan. Pada tahun 2016 mulai mengalami peningkatan kapitalisasi pasar, sehingga dapat diketahui perbandingan dari tahun 2015 dengan tahun 2016 mulai mengalami peningkatan kapitalisasi pasar dan tahun 2017 mulai membaik.

Penelitian-penelitian yang telah dilakukan sebelumnya tentang opini audit going concern menunjukkan hasil yang berbeda-beda. Hasil penelitian tersebut beragam, dikarenakan perbedaan sifat variabel yang diteliti, perbedaan sampel, periode pengamatan atau perbedaan metodologi yang digunakan. Keberagaman hasil penelitian-penelitian terdahulu menunjukkan bahwa penelitian ini perlu untuk diteliti kembali. Penelitian ini menarik untuk dilakukan karena untuk memverifikasi ulang hasil penelitian terdahulu tentang faktor-faktor apa saja yang mempengaruhi opini audit going concern pada perusahaan pertambangan yang terdaftar di Bursa Efek Indonesia.

Ada beberapa hal yang membuat penelitian ini berbeda dengan penelitian sebelumnya. Perbedaan utama terletak pada variabel yang digunakan. Penelitian ini menggunakan ukuran perusahaan, pertumbuhan perusahaan, solvabilitas dan opini audit tahun sebelumnya sebagai variabel independen. Periode pengamatan dalam penelitian ini yaitu dari tahun 2015-2017. Sehingga dapat diketahui perbandingan hasil penelitian ini dari tahun ke tahun. 
Penelitian yang dilakukan Alichia (2013) mengungkapkan bahwa auditor lebih sering mengeluarkan opini audit going concern pada perusahaan kecil karena auditor mempercayai bahwa perusahaan besar dapat menyelesaikan kesulitankesulitan yang dihadapinya daripada perusahaan kecil, hal ini dikarenakan perusahaan besar memiliki akses yang lebih muda dalam mendapatkan dana baik itu berupa pinjaman dari kreditur maupun dari sumber eksternal lainnya. Ukuran perusahaan dapat dinilai dari kondisi keuangan perusahaan, salah satunya dengan melihat total asset perusahaan. Total asset dijadikan sebagai ukuran perusahaan karena dari total asset yang dimiliki oleh perusahaan dapat dilihat bagaimana kelangsungan usaha perusahaan ke depannya, artinya semakin besar aset perusahaan maka semakin besar pula ukuran perusahaan tersebut. Berdasarkan penelitian Alichia (2013) dan Rakatenda dan Putra (2016) menemukan bahwa ukuran perusahaan berpengaruh terhadap opini audit going concern, sedangkan Wulandari (2014) dan Nariman (2017) menemukan bahwa ukuran perusahaan tidak berpengaruh terhadap opini audit going concern.

Pertumbuhan perusahaan juga dapat dijadikan indikator untuk menentukan apakah perusahaan dapat mempertahankan kelangsungan hidupnya. Menurut Sari dan Wahyuni (2014) mengatakan bahwa pertumbuhan perusahaan dapat ditunjukkan dengan peningkatan hasil usaha yang semakin meningkat dari periode ke periode. Perusahaan yang mengalami pertumbuhan laba positif menunjukkan aktivitas operasional perusahaan berjalan dengan semestinya sehingga perusahaan dapat mempertahankan posisi ekonominya dan kelangsungan hidupnya, sedangkan perusahaan dengan negative growth mengindikasikan kecenderungan yang lebih besar ke arah kebangkrutan. Penelitian yang dilakukan Alichia (2013) menemukan bahwa pertumbuhan perusahaan berpengaruh negatif terhadap opini audit going concern, artinya semakin tinggi tingkat pertumbuhan perusahaan semakin kecil kemungkinan diterimanya opini audit going concern.

Solvabilitas merupakan kemampuan suatu perusahaan untuk membayar semua hutang-hutangnya baik jangka pendek maupun jangka panjang (Ramadhani, 2016). Penelitian yang dilakukan oleh Sutedja (2010) menyatakan bahwa solvabilitas yang diproksikan dengan debt to assets ratio berpengaruh positif terhadap penerimaan opini audit going concern dari auditor, artinya apabila sebuah perusahaan memiliki rasio solvabilitas yang tinggi cenderung memiliki hutang yang tinggi pula. Hal ini akan meningkatkan resiko yang mungkin akan dihadapi oleh perusahaan, terutama dalam hal pembayaran hutang dan bunga. Perusahaan yang memiliki hutang yang tinggi akan cenderung mengalami kesulitan keuangan dan bisa mengakibatkan perusahaan berhenti beroperasi. Hal ini secara tidak langsung akan menimbulkan keraguan dari auditor atas kemampuan going concern perusahaan.

Selain ukuran perusahaan, pertumbuhan perusahaan, solvabilitas, pemberian opini going concern juga tidak terlepas dari opini audit yang diterima perusahaan pada tahun sebelumnya karena kegiatan usaha pada suatu perusahaan untuk tahun tertentu tidak terlepas dari kegiatan yang terjadi pada tahun sebelumnya. Menurut 
Khamidah dan Ardini (2017) menemukan bahwa opini audit tahun sebelumnya berpengaruh positif terhadap opini audit going concern. Hal ini menunjukkan jika tahun sebelumnya auditor memberikan opini going concern, maka semakin besar kemungkinan auditor untuk memberikan kembali opini going concern pada tahun berjalan. Hal ini dikarenakan hilangnya kepercayaan investor dan kreditor pada perusahaan tersebut sehingga perusahaan mengalami masalah keuangan seperti susah mendapatkan pinjaman, sehingga keadaan sulit yang terjadi sebelumnya tidak dapat diatasi dan berakibat buruk pada kelangsungan usaha perusahaan (Alichia, 2013). Opini audit going concern tahun sebelumya ini akan menjadi faktor pertimbangan penting auditor untuk mengeluarkan kembali opini audit going concern pada tahun berikutnya (Wulandari, 2014).

Berdasarkan uraian latar belakang di atas, dapat dirumuskan masalah dalam penelitian ini yaitu: apakah ukuran perusahaan, pertumbuhan perusahaan, solvabilitas dan opini audit tahun sebelumnya mempengaruhi opini audit going concern pada perusahaan pertambanngan yang terdaftar di bursa Efek Indonesia periode2015-2017. Tujuan penelitian ini adalah untuk mengetahui pengaruh ukuran perusahaan, pertumbuhan perusahaan, solvabilitas dan opini audit tahun sebelumnya terhadap opini audit going concern.

\section{LANDASAN TEORI DAN PERUMUSAN HIPOTESIS}

\section{Teori Keagenan (Agency Theory)}

Teori keagenan (agency theory) yang dikembangkan oleh Michael C. Jensen dan William H. Meckling (1976) menjelaskan adanya hubungan antara agen sebagai pihak yang mengelola perusahaan dan prinsipal sebagai pemilik, keduanya terikat dalam sebuah kontrak, artinya pemilik atau prinsipal adalah pihak yang melakukan evaluasi terhadap informasi dan agen sebagai pihak yang melaksanakan pekerjaan dan mengambil keputusan (Setiawan dan Suryono, 2015). Sehingga agen berkewajiban memberikan informasi yang relevan tentang keadaan perusahaan kepada prinsipal. Informasi yang diberikan salah satunya adalah informasi keuangan yang pengungkapannya didasarkan pada laporan keuangan perusahaan (Azmi dan Putra, 2014). Namun, tidak semua informasi yang ada pada laporan keuangan akan disajikan manajemen kepada prinsipal. Keadaan ini disebut asimetri informasi, dimana manajemen lebih banyak memiliki informasi dalam mengelola perusahaan dari pada prinsipal.

Pada praktiknya, manajemen tidak mengungkapkan informasi yang diperkirakan akan merugikan dirinya sehingga bisa terjadi manipulasi atas laporan keuangan (Setiawan dan Suryono, 2015). Hal ini berarti, laporan keuangan tidak dibuat berdasarkan keadaaan yang sebenarnya, tetapi dibuat berdasarkan keinginan manajemen, hal ini memicu terjadinya konflik keagenan dan dibutuhkan pihak ketiga yang independen yaitu auditor independen, karena auditor bisa kinerja agen berdasarkan laporan keuangan yang diauditnya. Dari laporan keuangan tersebut auditor akan memberikan opininya tentang laporan keuangan yang diaudit wajar atau tidak dan menilai mengenai kelangsungan hidup dari perusahaan apakah 
perusahaan tersebut mampu mempertahankan kelangsungan usahanya atau tidak (Khamidah dan Ardini, 2017).

\section{Opini Auditor}

Menurut Ikatan Akuntan Publik Indonesia (2011), auditing adalah proses pengumpulan dan pengevaluasian bahan bukti tentang informasi yang dapat diukur mengenai suatu entitas ekonomi yang dilakukan oleh seorang yang kompeten dan independen. Dalam melakukan audit, auditor harus mengumpulkan bukti-bukti mengenai kewajaran informasi yang tercantum dalam laporan keuangan perusahaan dengan cara memeriksa catatan akuntansi yang mendukung laporan tersebut sehingga auditor dapat memberikan pendapatnya mengenai kewajaran dari laporan keuangan perusahaan (Arsianto dan Rahardjo, 2013). Penelitian yang dilakukan Sari dan Wahyuni menyatakan bahwa opini audit merupakan pernyataan pendapat yang diberikan oleh auditor dalam menilai kewajaran penyajian laporan keuangan klien yang diauditnya. Opini audit disampaikan dalam tiga paragraf yaitu paragraf pengantar, paragraf lingkup dan paragraf pendapat. Auditor menyatakan pendapat atas laporan keuangan yang diaudit pada paragraf pendapat.

\section{Opini Audit Going Concern}

Opini auditgoing concern merupakan opini yang dikeluarkan auditor untuk memastikan apakah perusahaan dapat mempertahankan kelangsungan hidupnya (IAPI, 2011). Auditor bertanggung jawab mengevaluasi apakah terdapat kesangsian terhadap kemampuan entitas dalam mempertahankan kelangsungan hidupnya (Kartika, 2012). Auditor dapat mengidentifikasi informasi mengenai kondisi atau peristiwa tertentu yang menunjukkan adanya kesangsian besar tentang kemampuan entitas dalam mempertahankan kelangsungan hidupnya dalam jangka waktu pantas, yaitu tidak lebih dari satu tahun sejak tanggal laporan keuangan yang sedang diaudit (SA Seksi 341 paragraf : 6).

\section{Perumusan Hipotesis}

\section{Pengaruh Ukuran Perusahaan terhadap Opini Audit Going Concern}

Ukuran suatu perusahaan dapat diketahui salah satunya dengan melihat total aset perusahaan. Total aset dijadikan sebagai ukuran perusahaan karena dari total aset yang dimiliki oleh perusahaan dapat dilihat bagaimana kelangsungan usaha perusahaan ke depannya (Arsianto dan Rahardjo, 2013). Semakin tinggi total aset yang dimiliki perusahaan, maka perusahaan dianggap sebagai perusahaan besar sehingga mampu menjaga kelangsungan hidup usahanya dan kemungkinan perusahaan akan menerima opini audit non going concern. Berdasarkan penelitian yang dilakukan Rakatenda dan Putra (2016) menemukan bahwa ukuran perusahaan berpengaruh terhadap opini audit going concern. Hal ini menunjukkan semakin besar ukuran perusahaan maka akan semakin kecil kemungkinan perusahaan tersebut 
menerima opini audit going concern. Berdasarkan uraian tersebut, hipotesis yang akan diuji yaitu:

$H_{1}$ : Ukuran perusahaan berpengaruh terhadap opini audit going concern

\section{Pengaruh Pertumbuhan Perusahaan terhadap Opini Audit Going Concern}

Pertumbuhan perusahaan menunjukkan kemampuan perusahaan dalam mempertahankan kelangsungan usahanya. Perusahaan yang mengalami pertumbuhan menunjukkan aktivitas operasional perusahaan berjalan dengan baik sehingga perusahaan dapat mempertahankan kelangsungan hidupnya. Perusahaan dengan rasio pertumbuhan laba negatif berpotensi besar mengalami kebangkrutan sehingga apabila manajemen tidak segera mengambil tindakan perbaikan, perusahaan diragukan dapat melanjutkan hidupnya (Sari dan Wahyuni, 2014). Berdasarkan penelitian yang dilakukan oleh Alichia (2013), menemukan bahwa semakin besar pertumbuhan laba perusahaan maka semakin kecil kemungkinan perusahaan tersebut menerima opini audit going concern. Berdasarkan uraian tersebut, hipotesis yang akan diuji yaitu:

$\mathrm{H}_{2}$ : Pertumbuhan perusahaan berpengaruh terhadap opini audit going concern

\section{Pengaruh Solvabilitas terhadap Opini Audit Going Concern}

Solvabilitas merupakan kemampuan suatu perusahaan dalam rangka membayar semua hutang-hutangnya baik hutang jangka pendek maupun hutang jangka panjang. Berdasarkan penelitian yang dilakukan Sutedja (2010), menyatakan bahwa solvabilitas berpengaruh terhadap opini audit going concern. Apabila sebuah perusahaan memiliki rasio solvabilitas yang tinggi cenderung memiliki hutang yang tinggi pula. Hal ini akan meningkatkan resiko yang mungkin akan dihadapi oleh perusahaan terutama dalam hal pembayaran hutang dan bunga. Perusahaan yang memiliki hutang yang tinggi cenderung mengalami kesulitan keuangan. Hal ini secara tidak langsung akan menimbulkan keraguan dari auditor atas kemampuan going concern perusahaan. Berdasarkan uraian tersebut maka hipotesis yang akan diuji yaitu:

$H_{3}$ : Solvabilitas berpengaruh terhadap opini audit going concern.

\section{Pengaruh Opini Audit Tahun Sebelumnya terhadap Opini Audit Going Concern}

Penelitian yang dilakukan Sutedja (2010) dan Khamidah dan Ardini (2017) menemukan bahwa opini audit tahun sebelumnya berpengaruh terhadap opini audit going concern. Hal ini berarti perusahaan yang menerima opini going concern pada tahun sebelumnya, dianggap memiliki masalah kelangsungan hidupnya, sehingga semakin besar kemungkinan auditor untuk mengeluarkan opini audit going concern 
pada tahun berjalan. Berdasarkan uraian tersebut maka hipotesis yang akan diuji yaitu:

$H_{4}$ : Opini audit tahun sebelumnya berpengaruh terhadap opini audit going concern

\section{METODE PENELITIAN}

\section{Jenis Penelitian}

Penelitian ini merupakan penelitian kuantitatif yang berbentuk asosiatif. Penelitian kuantitatif menekankan pada pengujian teori-teori melalui pengukuran variabelvariabel penelitian dengan angka serta data dianalisis dengan menggunakan prosedur statistik. Sedangkan Penelitian asosiatif bertujuan untuk mengetahui pengaruh ataupun juga hubungan antara dua variabel atau lebih (Sugiyono, 2012).

\section{Populasi dan Sampel}

Populasi yang digunakan dalam penelitian ini adalah perusahaan-perusahaan pertambangan yang terdaftar di Bursa Efek Indonesia tahun 2015-2017. Pemilihan sampel dilakukan dengan teknik purposive sampling, yaitu pemilihan sampel berdasarkan kriteria-kriteria tertentu. Dalam penelitian ini kriteria yang ditetapkan adalah sebagai berikut: (1) Perusahaan pertambangan yang terdaftar di Bursa Efek Indonesia secara berturut-turut untuk periode 2015-2017. (2) Perusahaan pertambangan yang mengalami kerugian (laba bersih setelah pajak yang negatif) minimal satu kali dalam periode pengamatan (Nursasi dan Maria, 2015). (3) Perusahaan tersebut menyampaikan data secara lengkap selama periode pengamatan 2015-2017. (4) Perusahaan yang tidak sedang berada pada proses delisting selama periode 2015-2017.

\section{Jenis Data Dan Sumber Data}

Jenis data yang digunakan dalam penelitian ini adalah data kuantitatif, seperti ukuran perusahaan, pertumbuhan perusahaan, dan solvabilitas. Sumber data dari penelitian ini adalah sumber data sekunder berupa laporan keuangan dan laporan tahunan perusahaan pertambangan yang terdaftar di Bursa Efek Indonesia pada tahun 20152017.

\section{Teknik Pengumpulan Data}

Teknik pengumpulan data yang digunakan dalam penelitian ini adalah teknik dokumentasi, dimana pengumpulan data tersebut dilakukan dengan melihat laporan auditor independen. Data diperoleh dengan mengakses melalui website Bursa Efek Indonesia (www.idx.co.id).

\section{Variabel Penelitian}


Adapun variabel yang digunakan dalam penelitian ini adalah variabel dependen dan variabel independen. Variabel dependennya adalah opini audit going concern. Sedangkan variabel independen terdiri dari ukuran perusahaan, pertumbuhan perusahaan, solvabilitas dan opini audit tahun sebelumnya.

\section{Variabel Dependen (Y)}

Variabel dependen dalam penelitian ini adalah opini audit going concern, yaitu opini audit yang dikeluarkan auditor untuk memastikan apakah perusahaan dapat mempertahankan kelangsungan hidupnya (IAPI, 2011). Opini audit going concern diukur dengan dummy yaitu untuk perusahaan yang menerima opini audit going concern diberi kode 1 dan untuk perusahaan yang menerima opini audit non going concern diberi kode 0 (Putra et al., 2016).

\section{Variabel Independen (X)}

a. Ukuran Perusahaan

Ukuran perusahaan (size) diukur menggunakan natural logaritma dari total aset yang dimiliki perusahaan (Rakatenda dan Putra, 2016). Hal ini karena ukuran perusahaan yang dilihat dari total aset dinyatakan dalam rupiah penuh sehingga membuat digit data terlalu besar, nilai dan juga sebarannya yang terlalu besar dari variabel lain sehingga menyebabkan fluktuasi data yang berlebihan.

\section{Ukuran Perusahaan $=\operatorname{Ln}($ total asset $)$}

b. Pertumbuhan Perusahaan

Rasio Pertumbuhan laba digunakan untuk melihat sejauh mana kemampuan suatu perusahaan dalam menghasilkan laba. Berdasarkan penelitian yang dilakukan oleh Alichia (2013), pertumbuhan perusahaan diukur dengan menggunakan rasio pertumbuhan laba sebagai berikut:

$$
\text { Pertumbuhan Laba }=\frac{\text { Laba }(\text { Rugi) Bersiht }- \text { Laba }(\text { Rugi }) \text { Bersih } t-1}{\text { Laba }(\text { Rugi }) \text { Bersih } t-1}
$$

\section{Dimana:}

Laba (Rugi) bersih $\mathrm{t}=$ Laba (rugi) bersih tahun sekarang

Laba (Rugi) bersih t-1 = Laba (rugi) bersih tahun lalu

c. Sovabilitas

Rasio sovabilitas digunakan untuk menilai kemampuan perusahaan dalam memenuhi kewajibannya baik kewajiban jangka pendek maupun kewajiban jangka panjang. Berdasarkan penelitian yang dilakukan Sutedja (2010), solvabilitas diukur menggunakan Debt to Asset Ratio (DAR) yang digunakan untuk mengetahui seberapa besar aset perusahaan dibiayai oleh utang. Dalam penelitian ini dapat dirumuskan sebagai berikut: 


$$
\text { Debt to Assets Ratio }(D A R)=\frac{\text { Total Liabilities }}{\text { Total Assets }}
$$

d. Opini Audit Tahun Sebelumnya

Opini audit tahun sebelumnya didefinisikan sebagai opini yang diterima perusahaan pada tahun sebelumnya. Opini audit tahun sebelumnya diukur dengan dummy yaitu untuk perusahaan yang menerima opini audit going concern diberi kode 1 dan untuk perusahaan yang menerima opini audit non going concern diberi kode 0 (Khamidah dan Ardini, 2017).

\section{MODEL DAN TEKNIK ANALISIS DATA}

\section{Analisis Statistik Deskriptif}

Statistik deskriptif digunakan untuk mendeskripsikan dan memberikan gambaran tentang distribusi frekuensi variabel-variabel dalam penelitian ini, seperti nilai maksimum (nilai tertinggi), minimum (nilai terendah), mean (rata-rata) dan standar deviasi. Berdasarkan data olahan SPSS yang meliputi opini audit going concern, ukuran perusahaan, pertumbuhan perusahaan, solvabilitas dan opini audit tahun sebelumnya maka dapat diketahui nilai maksimum, nilai minimum, rata-rata (mean) dan standar deviasi dari setiap variabel.

\section{Analisis Regresi Logistik}

Model analisis data yang digunakan dalam penelitian ini adalah regresi logistik. Regresi Logistik digunakan untuk mengetahui pengaruh variabel independen terhadap variabel dependen. Pada analisis regresi logistik tidak memerlukan lagi uji normalitas pada variabel bebasnya (Ghozali, 2013). Selain itu, pada regresi logistik juga mengabaikan heteroscedasticity, hal ini berarti variabel dependen tidak memerlukan homoscedasticity untuk masing-masing variabel independennya (Gujarati, 2003). Persamaan regresi logistik dalam penelitian ini adalah sebagai berikut:

$$
\text { GCO }=\alpha+\beta 1 . L n S I Z E+\beta 2 . G R O W T H+\beta 3 . \text { DAR + B4.PRIOP + e }
$$

Keterangan:

$\begin{array}{ll}\text { GCO } & \text { : Opini going concern } \\ \alpha & \text { : Konstanta }\end{array}$




$\begin{array}{ll}\text { Bi } & \text { : Koefisien regresi variabel independen } \\ \text { LnSize } & \text { : Logaritma natural ukuran perusahaan } \\ \text { Growth } & \text { : Pertumbuhan perusahaan } \\ \text { DAR } & \text { : Solvabilitas } \\ \text { PRIOP } & \text { : Opini audit tahun sebelumnya } \\ \text { e } & \text { : Standar error }\end{array}$

Adapun tahapan yang digunakan dalam pengujian dengan menggunakan regresi logistik dapat dijelaskan sebagai berikut:

\section{Menilai Kelayakan Model Regresi}

Kelayakan model regresi dapat dilihat dari pengujian Hosmer and Lemeshow's Goodness of Fit Test, output Hosmer and Lemeshow's Goodness of Fit Test. Pengujian ini dilakukan untuk menilai apakah model mampu memprediksi nilai observasinya atau sesuai dengan data sehingga model dapat dikatakan fit. Output dari Hosmer and Lemeshow's dianalisa dengan hipotesis sebagai berikut:

$H_{0}=$ Tidak ada perbedaan signifikan antara model dengan data (data cocok atau sesuai dengan model (Ghozali,2013).

$H_{1}=$ Ada perbedaan signifikan antara model dengan nilai observasinya sehingga goodness fit model tidak baik karena model tidak dapat memprediksi nilai observasinya (Ghozali, 2013).

Dasar pengambilan keputusan yaitu dengan memperhatikan nilai goodness of fit test pada bagian bawah uji Hosmer and Lemeshow's Goodness of Fit Test (Ghozali, 2013):

$H_{0}$ diterima, jika probabilitas $>0,05$

$H_{0}$ ditolak, jika probabilitas $<0,05$

\section{Menilai Keseluruhan Model (Overall Model Fit Test)}

Pengujian dilakukan untuk mengetahui apakah model fit dengan data baik sebelum maupun sesudah dilakukan penambahan variabel independen kedalam model. Pengujian dilakukan dengan membandingkan nilai antara -2 Log Likelihood (-2LL) awal (Block Number 0 = Begining Block) dengan nilai -2 Log Likelihood (-2LL) akhir (Block Number 1). Apabila nilai -2LL awal lebih besar dari nilai -2LL akhir, maka keseluruhan model menunjukkan model regresi yang baik. Penurunan Log Likelihood 
menunjukkan model semakin baik (Ghozali, 2013). Hipotesis untuk menilai model fit adalah sebagai berikut:

$H_{0}$ : Model yang dihipotesiskan fit dengan data.

$H_{a}$ : Model yang dihipotesiskan tidak fit atau tidak cocok dengan data.

\section{Menilai Koefisien Determinasi (Nagelkerke R square)}

Nilai koefisien determinasi pada model regresi logistik dapat dilihat pada nilai Nagelkerke $R$ square. Nagelkerke $R$ Square merupakan pengujian yang dilakukan untuk mengetahui seberapa besar variabilitas variabel dependen dapat dijelaskan oleh varibilitas variabel independen sedangkan sisanya dipengaruhi oleh variabel lain yang tidak dimasukkan dalam model ini (Ghozali, 2013).

\section{Tabel Klasifikasi}

Tabel klasifikasi menunjukkan kekuatan prediksi dari model regresi untuk memprediksi kemungkinan perusahaan menerima opini going concern. Berdasarkan output regresi logistik, angka ini dapat dilihat pada classification table (Ghozali, 2013).

\section{Uji Multikolinearitas}

Uji multikolinearitas bertujuan untuk menguji apakah terjadi korelasi antar variabel independen. Model regresi yang baik seharusnya tidak terjadi korelasi yang kuat diantara variabel independen (Ghozali, 2013). Pada regresi logistik, menggunakan matrik korelasi antar variabel bebas untuk melihat besarnya korelasi antar variabel independen. Kriteria pengambilan keputusan dengan menggunakan matrik korelasi adalah sebagai berikut:

a. Jika nilai koefisien korelasi antar variabel bebas $<0,9$ berarti tidak terjadi multikolinearitas (Sarwono, 2016).

b. Jika nilai koefisien korelasi antar variabel bebas $>0,9$ berarti terjadi multikolinearitas (Sarwono, 2016).

\section{Uji koefisien Regresi}

Tahap akhir adalah uji koefisien regresi, hasilnya dapat dilihat pada tabel variable in the equation hasil output SPSS. Koefisien regresi dari tiap variabel-variabel yang diuji menunjukkan hubungan antar variabel tersebut. 


\section{Pengujian Hipotesis}

Pengujian hipotesis dilakukan dengan cara membandingkan nilai signifikansi dengan tingkat siginifikansi $(\alpha=0,05)$. Kriteria pengambilan keputusan untuk menguji hipotesis ini yaitu:

a. Jika signifikan $>0,05$ maka hipotesis di tolak. Artinya variabel independen tidak berpengaruh terhadap variabel dependen.

b. Jika signifikan $<0,05$, maka hipotesis diterima. Artinya variabel independen berpengaruh terhadap variabel dependen.

\section{ANALISIS DATA DAN PEMBAHASAN \\ Deskripsi Objek Penelitian}

Perusahaan yang menjadi sampel dalam penelitian ini adalah seluruh perusahaan pertambangan yang terdaftar di Bursa Efek Indonesia pada tahun 2015 sampai 2017. Pemilihan sampel dilakukan dengan metode purposive sampling, yaitu pemilihan sapel berdasarkan kriteria-kriteria tertentu. Berikut merupakan tabel seleksi sampel penelitian:

Tabel 4.1

Seleksi Sampel Penelitian

\begin{tabular}{|l|c|}
\hline Kriteria Sampel & Jumlah \\
\hline Perusahaan pertambangan yang terdaftar di BEI periode 2015-2017 & 36 \\
\hline Perusahaan yang mendapatkan laba positif & $(16)$ \\
\hline Jumlah perusahaan yang menjadi sampel & 20 \\
\hline Tahun pengamatan 2015-2017 & 3 \\
\hline Total Sampel & 60 \\
\hline
\end{tabular}

Sumber: Data Sekunder Diolah, 2018

Berdasarkan metode purposive sampling, perusahaan pertambangan yang memenuhi kriteria berjumlah 20 perusahaan per tahun dengan periode penelitian 3 tahun, sehingga total perusahaan yang dijadikan sampel dalam penelitian ini sebanyak 60 perusahaan.

\section{Analisis Statistik Deskriptif}

Analisis statistik deskriptif digunakan untuk mendeskripsikan dan memberikan gambaran tentang distribusi data dalam penelitian ini, seperti nilai tertinggi (maksimum), nilai terendah (minimum), rata-rata (mean) dan standar deviasi dari masing-masing variabel. Paparan ini bertujuan untuk memperoleh gambaran umum dari sekumpulan sampel yang diteliti, sehingga dapat menyimpulkan data secara 
mudah, cepat dan mempermudah pengamatan terhadap sampel tersebut. Adapun penjelasan statistik deskriptif dari masing-masing variabel adalah sebagai berikut:

\section{Variabel Dependen (Y)}

Berdasarkan tabel 4.3 dapat dilihat bahwa jumlah data yang digunakan dalam penelitian ini sebanyak 60 data. Variabel dependennya adalah opini audit going concern. Sampel penelitian yang memperoleh opini audit non going concern sebanyak 41 sampel atau 68,3\%, sedangkan sampel yang memperoleh opini audit going concern sebanyak 19 sampel atau 31,7\%. Berikut merupakan hasil statistik deskriptif opini audit going concern:

Tabel 4.3

Statistik Deskriptif Frekuensi Opini Audit Going Concern

\begin{tabular}{|c|c|c|c|c|}
\hline & Frequency & Percent & Valid Percent & $\begin{array}{c}\text { Cumulative } \\
\text { Percent }\end{array}$ \\
\hline OPINI NON GCO & 41 & 68.3 & 68.3 & 68.3 \\
OPINI GCO & 19 & 31.7 & 31.7 & 100.0 \\
Total & 60 & 100.0 & 100.0 & \\
\hline
\end{tabular}

Sumber: Output IBM SPSS ver. 20

\section{Variabel Independen (X)}

\section{a. Ukuran Perusahaan}

Berdasarkan tabel 4.4 dapat dilihat bahwa jumlah data (N) yang digunakan dalam penelitian ini sebanyak 60 data. Variabel ukuran perusahaan (size) memiliki nilai minimum sebesar 25,6459 pada PT Perdana Karya Perkasa Tbk sedangkan nilai maksimumnya adalah 31,8783 pada PT Medco Energi International Tbk. Rata-rata variabel size adalah 28,9339 yang artinya ratarata total aset yang dimiliki perusahaan sebesar 2893\% sedangkan standar deviasinya sebesar 1,5881 lebih kecil dari angka rata-rata artinya data menyebar secara merata dan tidak terjadi begitu banyak penyimpangan data dalam penelitian ini. Berikut merupakan hasil statistik deskriptif variabel ukuran perusahaan: 
Tabel 4.4

Statistik Deskriptif Ukuran Perusahaan

\begin{tabular}{|c|c|c|c|c|c|}
\hline & $\mathrm{N}$ & Minimum & Maximum & Mean & Std. Deviation \\
\hline $\begin{array}{c}\text { SIZE } \\
\text { Valid N } \\
\text { (listwise) }\end{array}$ & 60 & 25.645900 & 31.878350 & 28.93388050 & 1.588115975 \\
\hline
\end{tabular}

Sumber: Output IBM SPSS ver. 20

\section{b. Pertumbuhan Perusahaan}

Berdasarkan tabel 4.5 dapat dilihat bahwa jumlah data $(\mathrm{N})$ yang digunakan dalam penelitian ini sebanyak 60 data. Nilai minimum variabel pertumbuhan perusahaan (growth) adalah -24,5978 yang dimiliki oleh PT Mitra Investindo Tbk sedangkan nilai maksimumnya adalah 17,9190 yang dimiliki oleh PT Bayan Resources Tbk. Rata-ratanya sebesar -1,2787 artinya rata-rata keberhasilan perusahaan mampu mempertahankan pertumbuhan labanya sebesar $-127,87 \%$ sedangkan standar deviasi sebesar 6,4135 lebih besar dari rata-rata artinya data yang diperoleh tidak menyebar secara merata. Berikut merupakan hasil statistik deskriptif variabel pertumbuhan perusahaan:

Tabel 4.5

Statistik Deskriptif Pertumbuhan Perusahaan

\begin{tabular}{|c|c|c|c|c|c|}
\hline & $\mathrm{N}$ & Minimum & Maximum & Mean & Std. Deviation \\
\hline $\begin{array}{c}\text { GROWTH } \\
\begin{array}{c}\text { Valid N } \\
\text { (listwise) }\end{array}\end{array}$ & 60 & -24.597770 & 17.919050 & -1.27870117 & 6.413474026 \\
\hline
\end{tabular}

Sumber: Output IBM SPSS ver. 20

\section{c. Solvabilitas}

Berdasarkan tabel 4.6 dapat dilihat bahwa jumlah data $(\mathrm{N})$ yang digunakan dalam penelitian ini sebanyak 60 data. Nilai minimum variabel solvabilitas (DAR) sebesar 0,0235 yang dimilliki oleh PT Cakra Mineral Tbk sedangkan nilai maksimumnya adalah 0,8978 yang dimiliki oleh PT Delta Dunia Makmur Tbk. Rata-rata variabel DAR sebesar 0,4808 yang artinya rata-rata kemampuan perusahaan dalam memenuhi kewajiban sebesar 48,08\%, sedangkan standar deviasinya adalah 0,2453 . Nilai standar deviasi lebih kecil 
dari nilai rata-rata yang berarti data menyebar secara merata dan tidak terjadi begitu banyak penyimpangan data dalam penelitian ini.

Tabel 4.6

Statistik Deskriptif Solvabilitas

\begin{tabular}{|c|c|c|c|c|c|}
\hline & $\mathrm{N}$ & Minimum & Maximum & Mean & Std. Deviation \\
\hline DAR & 60 & .023550 & .897810 & .48078917 & .245346917 \\
$\begin{array}{c}\text { Valid N } \\
\text { (listwise) }\end{array}$ & 60 & & & & \\
\hline
\end{tabular}

Sumber: Output IBM SPSS ver. 20

\section{d. Opini Audit Tahun Sebelumnya}

Berdasarkan tabel 4.7 dapat dilihat bahwa sampel yang mendapatkan opini audit going concern pada tahun sebelumnya sebanya 17 sampel atau 28,3\%, sedangkan sampel yang mendapatkan opini audit non going concern sebanyak 43 sampel atau $71,7 \%$.

Tabel 4.7

Statistik Deskriptif Frekuensi Opini Audit Tahun Sebelumnya

\begin{tabular}{|cc|c|c|c|c|}
\hline & & Frequency & Percent & $\begin{array}{c}\text { Valid } \\
\text { Percent }\end{array}$ & $\begin{array}{c}\text { Cumulative } \\
\text { Percent }\end{array}$ \\
\hline \multirow{2}{*}{ Valid } & OPINI NON GCO & 43 & 71.7 & 71.7 & 71.7 \\
& OPINI GCO & 17 & 28.3 & 28.3 & 100.0 \\
& Total & 60 & 100.0 & 100.0 & \\
\hline
\end{tabular}

Sumber: Output IBM SPSS ver. 20

\section{Analisis Regresi Logistik}

Analisis regresi logistik digunakan untuk menguji pengaruh ukuran perusahaan (size), pertumbuhan perusahaan (growth), solvabilitas (DAR), dan opini audit tahun sebelumnya (PRIOP) terhadap opini audit going concern. Pada analisis regresi logistik tidak memerlukan lagi uji normalitas dan uji asumsi klasik pada variabel bebasnya (Ghozali, 2013). Selain itu, regresi logistik juga mengabaikan heteroscedasticity, artinya variabel dependen tidak memerlukan homoscedasticity untuk masing-masing variabel independenya (Gurajati, 2003). 


\section{a. Uji Kelayakan Model Regresi}

Hasil ouput regresi logistik untuk uji Hosmer and Lemeshow menunjukkan bahwa besarnya nilai Hosmer and Lemeshow Goodness of Fit Test sebesar 4,127 dengan probabilitas signifikansi sebesar 0,845. Tingkat signifikansi tersebut lebih besar dari 0,05, maka hipotesis nol diterima. Hal ini berarti model mampu memprediksi nilai observasinya atau dapat dikatakan model fit dengan data (Ghozali, 2013). Oleh karena itu model regresi layak digunakan dalam analisis selanjutnya. Berikut ini hasil uji Hosmer dan Lemeshow Goodness of Fit Test:

Tabel 4.8

Hosmer and Lemeshow Test

\begin{tabular}{|c|c|c|c|}
\hline Step & Chi-square & Df & Sig. \\
\hline 1 & 4.127 & 8 & .845 \\
\hline
\end{tabular}

Sumber: Output IBM SPSS ver. 20

\section{b. Uji Keseluruhan Model (Overall Model Fit)}

Penilaian keseluruhan model dilakukan dengan membandingkan nilai antara 2 Log Likelihood (-2LL) pada awal (Block Number =0) dengan niali -2 Log Likelihood (-2LL) pada akhir (Block Number $=1$ ). Hasil regresi logistik menunjukkan angka pada -2LL awal sebesar 74,920 yang dapat dilihat pada tabel berikut:

Tabel 4.9

Iteration History (-2LL Awal)

\begin{tabular}{|cc|c|c|}
\hline \multicolumn{2}{|c|}{ Iteration } & -2 Log likelihood & Coefficients \\
\cline { 4 - 4 } & & & Constant \\
\hline \multirow{3}{*}{ Step 0 } & 1 & 74.936 & -.733 \\
& 2 & 74.920 & -.769 \\
& 3 & 74.920 & -.769 \\
\hline
\end{tabular}

Sumber: Output IBM SPSS ver. 20

Sedangkan nilai -2LL akhir (Block Number $=1$ ) adalah sebesar 19,616. Hal ini menunjukkan terjadi penurunan nilai -2LL awal dan -2LL akhir sebesar $74,920-19,616=55,304$. Artinya keseluruhan model regresi yang digunakan dalam penelitian ini merupakan model yang baik atau dapat dikatakan model fit sehingga hipotesil nol diterima (Ghozali, 2013). Hasil uji -2LL akhir dapat dilihat pada tabel berikut: 
Tabel 4.10

Iteration History (-2LL Akhir)

\begin{tabular}{|c|c|c|c|c|c|c|}
\hline & \multirow{2}{*}{$\begin{array}{c}-2 \text { Log } \\
\text { likelihood }\end{array}$} & \multicolumn{5}{|c|}{ Coefficients } \\
\hline Iteration & & Constant & SIZE & GROWTH & DAR & $\begin{array}{c}\text { PRIOP( } \\
\text { 1) }\end{array}$ \\
\hline 1 & 30.146 & 3.738 & -.184 & -.037 & -.402 & 3.561 \\
\hline 2 & 22.951 & 10.049 & -.422 & -.080 & -1.188 & 5.334 \\
\hline 3 & 20.530 & 17.242 & -.678 & -.117 & -2.566 & 6.932 \\
\hline Step 4 & 19.763 & 23.858 & -.910 & -.144 & -3.990 & 8.387 \\
\hline 5 & 19.623 & 28.167 & -1.063 & -.155 & -4.822 & 9.310 \\
\hline 6 & 19.616 & 29.435 & -1.108 & -.157 & -5.038 & 9.571 \\
\hline 7 & 19.616 & 29.518 & -1.111 & -.157 & -5.051 & 9.588 \\
\hline 8 & 19.616 & 29.518 & -1.111 & -.157 & -5.051 & 9.588 \\
\hline
\end{tabular}

Sumber: Output IBM SPSS ver. 20

Hasil pengurangan -2LL awal dengan -2LL akhir dapat dilihat pada tabel omnibus tests of model coefficients yaitu pada kolom chis-square. Pada tabel 4.11, mempunyai nilai signifikansi sebesar 0,000 lebih kecil dari 0,05. Hal ini berarti, secara simultan variabel independen mempengaruhi variabel dependen (Hidayat, 2017).

Tabel 4.11

Omnibus Tests of Model Coefficients

\begin{tabular}{|cc|c|c|c|}
\hline & & Chi-square & df & Sig. \\
\hline \multirow{3}{*}{ Step 1 } & Step & 55.304 & 4 & .000 \\
& Block & 55.304 & 4 & .000 \\
& Model & 55.304 & 4 & .000 \\
\hline
\end{tabular}

Sumber: Output IBM SPSS ver. 20

\section{c. Uji Koefisien Determinasi}

Nilai koefisien determinasi pada model regresi logistik dapat dilihat pada nilai Nagelkerke $R$ square. Berdasarkan hasil regresi logistik, nilai Nagelkerke $R$ Square sebesar 0,844. Hal ini berarti, variabilitas variabel dependen yang dapat dijelaskan oleh variabilitas variabilitas variabel independen sebesar 
$84,4 \%$, sedangkan sisanya sebesar $15,6 \%$ dijelaskan oleh variabel-variabel lain diluar model penelitian (Ghozali, 2013). Hasil uji koefisien determinasi dapat dilihat pada tabel 4.12 berikut:

Tabel 4.12

Model Summary

\begin{tabular}{|c|c|c|c|}
\hline Step & -2 Log likelihood & $\begin{array}{c}\text { Cox \& Snell R } \\
\text { Square }\end{array}$ & Nagelkerke R Square \\
\hline 1 & $19.616^{\mathrm{a}}$ & .602 & .844 \\
\hline
\end{tabular}

Sumber: Output IBM SPSS ver. 20

\section{d. Uji Tabel Klasifikasi}

Tabel klasifikasi menunjukkan kekuatan prediksi dari model regresi untuk memprediksi penerimaan opini going concern pada perusahaan. Berdasarikan hasil uji tabel klasifikasi (Tabel 4.13), dapat disimpulkan bahwa kekuatan prediksi dari model regresi untuk memprediksi kemungkinan perusahaan menerima opini audit going concern adalah sebesar 89,5\%. Hal ini menunjukkan bahwa dengan menggunakan model regresi ada 17 perusahaan yang mendapatkan opini audit going concern dari total 19 perusahaan yang seharusnya memperoleh opini going concern. Kekuatan prediksi model perusahaan yang menerima opini non going concern sebesar 97,6\%. Hal ini berarti ada sebanyak 40 perusahaan yang menerima opini non going concern dari total 41 perusahaan yang seharusnya menerima opini audit non going concern. Berikut merupakan tabel klasifikasi hasil regresi logistik:

Tabel 4.13

\section{Classification Table}

\begin{tabular}{|c|c|c|c|}
\hline \multirow{2}{*}{ OBSERVED } & \multicolumn{3}{|c|}{ Predicted } \\
\cline { 2 - 3 } & \multicolumn{2}{|c|}{ OPINI } & Percentage \\
& Correct \\
\cline { 2 - 3 } & NON GCO & GCO & \\
\hline \multirow{2}{*}{ OPINI OPINI NON GCO } & 40 & 1 & 97.6 \\
OVINI GCO & 2 & 17 & 89,5 \\
OVERALL PERCENTAGE & & & 95,0 \\
\hline
\end{tabular}

Sumber: Output IBM SPSS ver. 20

\section{e. Uji Multikolinearitas}

Uji multikolinearitas bertujuan untuk menguji apakah terjadi korelasi antar variabel independen. Multikolinearitas dapat diketahui dari nilai koefisien korelasi yang didapat dari hasil correlations matrix dari hasil Regresi Logistik. Jika nilai koefisien korelasi diantara masing-masing variabel bebas lebih dari 
0,9, maka terjadi multikolinearitas (Sarwono, 2016). Berikut adalah tabel hasil correlation matrix yang diperoleh dalam penelitian ini:

Tabel 4.14

Correlation Matrix

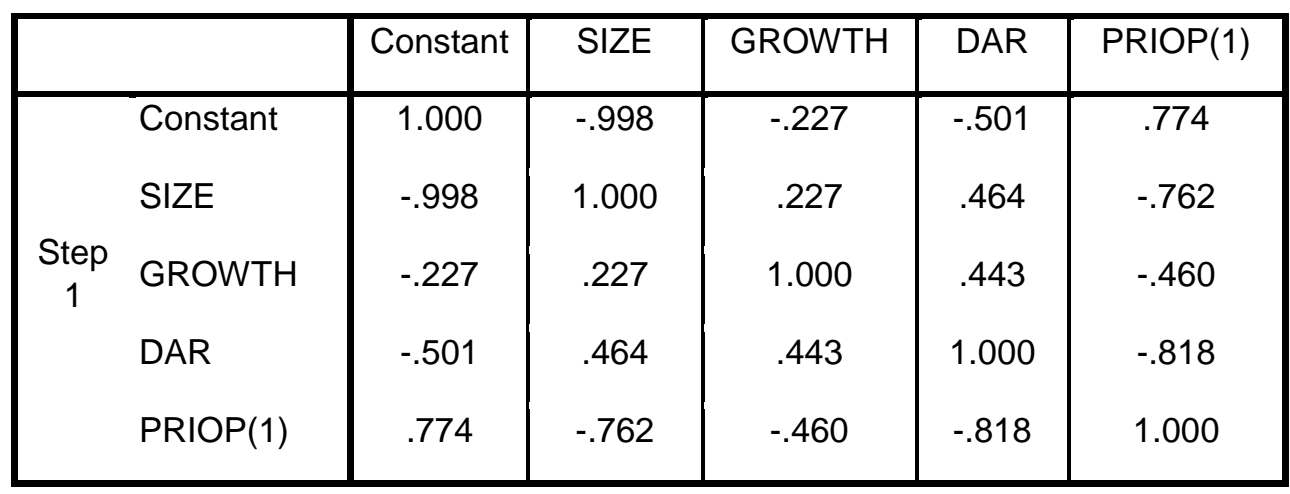

Sumber: Output IBM SPSS ver. 20

Berdasarkan tabel diatas, dapat diketahui bahwa tidak ada nilai koefisien korelasi dari masing-masing variabel yang menunjukkan lebih dari 0,9. Sehingga, dapat disimpulkan bahwa tidak ada masalah multikolinearitas dalam penelitian ini (Sarwono, 2016).

\section{f. Uji Koefisien Regresi}

Tahap akhir adalah uji koefisien regresi, hasinya dapat dilihat pada tabel variable in the equation sebagai berikut:

Tabel 4.15

Variabel in the Equation

\begin{tabular}{|l|c|c|c|c|c|c|}
\hline & B & S.E. & Wald & df & Sig. & Exp(B) \\
\hline SIZE & -1.111 & .656 & 2.872 & 1 & .090 & .329 \\
GROWTH & -.157 & .103 & 2.327 & 1 & .127 & .854 \\
DAR & -5.051 & 3.940 & 1.644 & 1 & .200 & .006 \\
PRIOP(1) & 9.588 & 3.564 & 7.239 & 1 & .007 & 14589.893 \\
Constant & 29.518 & 18.364 & 2.584 & 1 & .108 & 6600863838829.9 \\
\hline
\end{tabular}

Sumber: Output IBM SPSS ver. 20

Persamaan model regresi yang terbentuk berdasarkan tabel diatas adalah sebagai berikut: 
GCO $=\alpha+\beta 1$. LnSIZE + $\beta 2$. GROWTH + $\beta 3$. DAR + B4.PRIOP + e

Keterangan:

$\begin{array}{ll}\text { GCO } & \text { : Opini going concern } \\ \text { LnSIZE } & \text { : Logaritma natural ukuran perusahaan } \\ \text { GROWTH } & \text { : Pertumbuhan perusahaan } \\ \text { DAR } & \text { : Solvabilitas } \\ \text { PRIOP } & : \text { Opini audit tahun sebelumnya } \\ \text { e } & : \text { Standar error }\end{array}$

Dari persamaan regresi tersebut, dapat diinterpretasikan bahwa dengan konstanta sebesar 29,518 menunjukkan jika variabel independen yaitu ukuran perusahaan $(\beta 1)$, pertumbuhan perusahaan $(\beta 2)$, solvabilitas $(\beta 3)$, dan opini audit tahun sebelumnya $(\beta 4)$ dianggap konstan, maka opini audit going concern sebagai variabel dependen naik sebesar 29,518. Hasil koefisien regresi untuk masing-masing variabel independen dari tabel diatas dapat dijelaskan sebagai berikut:

a. Ukuran Perusahaan

Koefisien regresi variabel ukuran perusahaan (size) sebesar -1,111. Tanda negatif pada koefisien regresi menunjukkan hubungan yang berlawanan arah antara variabel independen dengan variabel dependennya. Hal ini menunjukkan untuk kenaikan ukuran perusahaan sebesar 0,01 akan menurunkan opini audit going concern sebesar 1,111.

b. Pertumbuhan Perusahaan

Koefisien regresi variabel pertumbuhan perusahaan (growth) adalah sebesar -0,157. Tanda negatif pada koefisien regresi menunjukkan hubungan yang berlawanan arah antara variabel independen dengan variabel dependennya. Hal ini menunjukkan untuk kenaikan ukuran perusahaan sebesar 0,01 akan menurunkan opini audit going concern sebesar 0,157.

c. Solvabilitas

Variabel solvabilitas memperoleh nilai koefisien regresi sebesar $-5,051$. Tanda negatif pada koefisien regresi menunjukkan hubungan yang berlawanan arah antara variabel independen dengan variabel dependennya. Hal ini berarti untuk kenaikkan variabel solvabilitas sebesar 0,01 akan menurunkan opini audit going concern sebesar 5,051.

d. Opini Audit Tahun Sebelumnya

Variabel opini audit tahun sebelumnya memperoleh koefisien regresi sebesar 9,588. Tanda positif pada nilai koefisien regresi menunjukkan hubungan yang searah antara variabel independen dengan variabel dependen. Hal ini berarti, untuk kenaikkan opini audit tahun sebelumya sebesar 0,01 akan menaikkan opini audit going concern sebesar 9,588. 


\section{PENGUJIAN HIPOTESIS DAN PEMBAHASAN}

Pengujian hipotesis dalam penelitian ini bertujuan untuk menguji apakah variabel independen yang dimasukkan dalam regresi logistik mempunyai pengaruh terhadap variabel dependen. Pengujian hipotesis dilakukan dengan membandingkan nilai sig dengan $\alpha=0,05$ yang terdapat pada tabel 4.15 . Jika tingkat signifikansi lebih kecil dari 0,05 maka hipotesis diterima, sedangkan jika tingkat signifikansi lebih besar dari 0,05, maka hipotesis ditolak.

\section{Ukuran Perusahaan Berpengaruh terhadap Opini Audit Going Concern}

Hipotesis pertama dalam penelitian ini yaitu ukuran perusahaan berpengaruh terhadap opini audit going concern. Ukuran perusahaan diproksikan dengan natural logaritma dari total aset. Hasil penelitian pada tabel 4.15 menunjukkan variabel ukuran perusahaan (size) memperoleh koefisien regresi sebesar -1,111 dan signifikansi sebesar 0,090. Tanda negatif pada koefisien regresi menunjukkan hubungan yang berlawanan arah antara variabel independen dengan variabel dependennya. Hal ini menunjukkan untuk kenaikan ukuran perusahaan sebesar 0,01 akan menurunkan opini audit going concern sebesar 1,111. Tingkat signifikansi sebesar 0,090 lebih besar dari 0,05 yang berarti hipotesis pertama ditolak. Sehingga dapat dikatakan bahwa ukuran perusahaan tidak berpengaruh terhadap opini audit going concern.

Hasil ini membuktikan bahwa baik perusahaan yang berukuran kecil maupun perusahaan yang berukuran besar mempunyai peluang yang sama dalam menerima opini audit going concern. Artinya, perusahaan yang memiliki ukuran yang besar tidak menentukan perusahaan tersebut untuk tidak mendapatkan opini audit going concern. Sebaliknya, perusahaan yang memiliki ukuran kecil juga tidak menentukan perusahaan tersebut mendapatkan opini audit going concern. Hal ini berarti, meskipun perusahaan tergolong dalam perusahaan kecil, namun jika perusahaan tersebut memiliki manajemen dan kinerja yang bagus sehingga perusahaan tersebut dapat bertahan dalam jangka panjang maka kemungkinan perusahaan tersebut menerima opini audit going concern juga semakin kecil. Sebaliknya, jika perusahaan tergolong perusahaan besar, namun tidak memiliki manajemen dan kinerja yang bagus maka besar kemungkinan perusahaan tersebut menerima opini audit going concern.

Hasil penelitian diatas didukung dengan kondisi PT Perdana Karya Perkasa Tbk yang memiliki ukuran perusahaan yang kecil namun perusahaan tersebut tidak mendapatkan opini audit going concern. Hasil penelitian ini konsisten dengan penelitian yang dilakukan oleh Kristiana (2012), Wulandari (2014) dan Nariman (2017) yang menemukan bahwa ukuran perusahaan yang diproksikan dengan natural logaritma total aset tidak berpengaruh terhadap opini going concern, namun hasil penelitian ini tidak mendukung penelitian yang dilakukan oleh Rakatenda dan Putra (2016) yang menemukan bahwa ukuran perusahaan yang diproksikan dengan natural logaritma total aset berpengaruh terhadap opini going concern. 


\section{Pertumbuhan Perusahaan Berpengaruh terhadap Opini Audit Going Concern}

Hipotesis kedua dalam penelitian ini yaitu pertumbuhan perusahaan berpengaruh terhadap penerimaan opini audit going concern. Hasil penelitian pada tabel 4.15 menunjukkan variabel pertumbuhan perusahaan memperoleh nilai koefisien regresi sebesar -0,157 dan signifikansi sebesar 0,127. Tanda negatif pada koefisien regresi menunjukkan hubungan yang berlawanan arah antara variabel independen dengan variabel dependennya. Hal ini menunjukkan untuk kenaikan ukuran perusahaan sebesar 0,01 akan menurunkan opini audit going concern sebesar 0,157. Tingkat signifikansi sebesar 0,127 lebih besar dari 0,05 yang berarti hipotesis kedua ditolak. Sehingga dapat dikatakan bahwa pertumbuhan perusahaan tidak berpengaruh terhadap opini audit going concern.

Hasil ini menunjukkan perusahaan yang memperoleh opini audit going concern maupun yang memperoleh opini audit non going concern sama-sama mengalami pertumbuhan laba yang negatif sehingga dapat dikatakan bahwa perusahaan yang mengalami pertumbuhan laba yang negatif tidak selalu memperoleh opini audit going concern. Hasil ini juga menunjukkan bahwa perusahaan yang mengalami pertumbuhan laba yang negatif namun selama saldo laba serta total ekuitasnya masih positif maka perusahaan masih dapat bertahan hidup sehingga auditor tidak menerbitkan opini audit going concern. Selain itu penelitian ini menemukan bahwa pertumbuhan laba yang positif juga tidak menjamin perusahaan tidak memperoleh opini audit going concern, dikarenakan walaupun perusahaan memperoleh pertumbuhan laba yang positif namun perusahaan masih mengalami defisit saldo laba atau bahkan total ekuitasnya negatif maka auditor akan meragukan kelangsungan hidup perusahaan sehingga menerbitkan opini audit going concern. Dengan demikian hasil penelitian ini menunjukkan bahwa auditor tidak mempertimbangkan pertumbuhan perusahaan dalam menerbitkan opini audit going concern.

Hasil penelitian ini didukung dengan kondisi keuangan PT Medco Energi International Tbk yang memiliki pertumbuhan laba negatif selama tahun 2015-2017 namun pertumbuhan laba yang negatif tersebut tidak memberikan pengaruh terhadap opini audit yang diterima PT Medco Energi International Tbk. Hasil ini juga sesuai dengan kondisi PT Atlas Resources Tbk yang memiliki laba positif pada tahun 2015 namun pertumbuhan laba tersebut tidak mempegaruhi opini audit yang diterima perusahaan tersebut. Hasil Penelitian ini konsisten dengan penelitian yang dilakukan oleh Putra et al., (2016), Khamidah dan Ardini (2017) dan Nariman (2017) namun hasil penelitian ini tidak mendukung penelitian yang telah dilakukan oleh Sari dan Wahyuni (2014).

\section{Solvabilitas Berpengaruh terhadap Opini Audit Going Concern}

Hipotesis ketiga yaitu solvabilitas berpengaruh terhadap opini audit going concern. Hasil penelitian pada tabel 4.15 menunjukkan variabel solvabilitas memperoleh nilai koefisien regresi sebesar $-5,051$ dan signifikansi sebesar 0,200. Tanda negatif pada koefisien regresi menunjukkan hubungan yang berlawanan arah antara variabel 
independen dengan variabel dependennya. Hal ini berarti untuk kenaikkan variabel solvabilitas sebesar 0,01 akan menurunkan opini audit going concern sebesar 5,051. Tingkat signifikansi sebesar 0,200 lebih besar dari 0,05 yang artinya hipotesis ketiga ditolak. Sehingga dapat dikatakan bahwa solvabilitas tidak berpengaruh terhadap opini audit going concern. Hasil ini menunjukkan bahwa auditor dalam memberikan opini audit going concern tidak hanya berdasarkan seberapa besar aset perusahaan yang dibiayai oleh utang akan tetapi lebih cenderung melihat kondisi keuangan perusahaan secara keseluruhan.

Hasil penelitian ini didukung dengan kondisi keuangan PT Delta Dunia Makmur Tbk yang memiliki rasio DAR yang besar namun perusahaan tersebut tidak menerima opini audit going concern. Penelitian ini sejalan dengan penelitian yang Ramadhani (2016) yang menemukan solvabilitas tidak berpengaruh terhadap opini going concern, namun penelitian ini tidak mendukung hasil penelitian yang dilakukan Sutedja (2010) yang menemukan bahwa solvabilitas berpengaruh terhadap opini audit going concern.

\section{Opini Audit Tahun Sebelumnya Berpengaruh Terhadap Opini Audit Going Concern}

Hipotesis keempat yaitu variabel opini audit tahun sebelumnya berpengaruh terhadap opini going concern. Hasil penelitian pada tabel 4.15 menunjukkan variabel opini audit tahun sebelumnya memperoleh koefisien regresi sebesar 9,588 dan tingkat signifikansi sebesar 0,007. Tanda positif pada nilai koefisien regresi menunjukkan hubungan yang searah antara variabel independen dengan variabel dependen. Hal ini berarti, untuk kenaikkan opini audit tahun sebelumya sebesar 0,01 akan menaikkan opini audit going concern sebesar 9,588. Tingkat signifikansi sebesar 0,007 lebih kecil dari 0,05 yang artinya hipotesis keempat diterima. Sehingga dapat dikatakan bahwa opini audit tahun sebelumnya berpengaruh terhadap opini audit going concern.

Hasil penelitian ini menjelaskan bahwa bila tahun sebelumnya perusahaan mendapatkan opini going concern maka besar kemungkinan akan mendapatkan opini yang sama pada tahun berikutnya, karena auditor dalam memberikan opini atas hasil auditnya akan memperhatikan pada opini yang diterima perusahaan pada tahun sebelumnya, selain itu kegiatan usaha perusahaan yang terjadi pada tahun berjalan tidak terlepas dari keadaan yang terjadi pada tahun sebelumnya sehingga auditor berpotensi untuk menerbitkan kembali opini yang sama pada tahun berjalan. Hal ini dikarenakan opini going concern yang diterima pada tahun sebelumnya membuat perusahaan kehilangan kepercayaan dari investor dan kreditor sehingga keadaan sulit yang terjadi pada tahun sebelumnya tidak dapat diatasi seperti perusahaan sulit untuk mendapatkan pinjaman dari kreditor yang berakibat pada memburuknya kondisi perusahaan dan besar kemungkinan perusahaan akan menerima opini going concern pada tahun berjalan.

Hasil penelitian ini didukung dengan kondisi PT Atlas Resources Tbk, yang menerima opini going concern pada tahun sebelumnya sehingga pada tahun berjalan 
juga mendapatkan opini going concern. Hasil penelitian ini sejalan dengan hasil penelitian dilakukan Sutedja (2010), Kartika (2012), Wulandari (2014) dan Khamidah dan Ardini (2017) yang menemukan bahwa opini audit tahun sebelumnya berpengaruh terhadap opini going concern. Namun penelitian ini tidak mendukung hasil penelitian yang dilakukan Putra et., al (2016) yang menemukan bahwa opini audit tahun sebelumnya tidak berpengaruh terhadap penerimaan opini audit going concern.

\section{KESIMPULAN DAN SARAN}

\section{Kesimpulan}

Penelitian ini dilakukan untuk menguji faktor-faktor yang mempengaruhi opini audit going concern. Faktor-faktor tersebut yaitu, ukuran perusahaan, pertumbuhan perusahaan, solvabilitas dan opini audit tahun sebelumnya. Berdasarkan hasil analisis data, pengujian dan pembahasan maka dapat disimpulkan sebagai berikut: (1) Ukuran perusahaan yang diukur menggunakan natural logaritma dari total aset tidak berpengaruh terhadap opini audit going concern. (2) Pertumbuhan perusahaan yang diukur dengan pertumbuhan laba tidak berpengaruh terhadap opini audit going concern. (3) Solvabilitas yang diukur dengan debt to asset ratio tidak berpengaruh terhadap opini audit going concern. (4) Opini audit tahun sebelumnya berpengaruh terhadap opini audit going concern.

\section{Saran}

Penelitian ini diharapkan dapat memberikan masukan untuk penelitian selanjutnya. Berkaitan dengan hasil dalam penelitian ini, terdapat beberapa saran untuk penelitian selanjutnya adalah penelitian ini menggunakan perusahaan pertambangan yang terdaftar di BEI, penelitian selanjutnya dapat melakukan penelitian dengan objek yang berbeda sehingga dapat diketahui faktor-faktor yang mempengaruhi opini going concern pada berbagai macam sektor industri yang terdaftar di Bursa Efek Indonesia.Variabel ukuran perusahaan sebaiknya menggunakan alternartif pengukuran lain seperti penjualan, nilai kapitalisasi pasar sehingga dapat dilihat keberagaman hasil penelitian ini dan variabel pertumbuhan perusahaan sebaiknya menggunakan alternatif pengukuran lain selain laba sehingga dapat dilihat keberagaman hasil penelitian.

\section{REFERENSI}

Agung, Budi Santoso. (2017). Pengertian, Tutorial, dan Interpretasi Regresi Logistik dengan SPSS. Ditelusuri 11 Agustus 2018 pukul 20:21. https://agungbudisantoso.com.

Alichia, Yashinta Putri. (2013). Pengaruh Ukuran Perusahaan, Perumbuhan Perusahaan dan Opini Audit Tahun Sebelumnya terhadap Opini Audit Going 
Concern: Studi Empiris pada Perusahaan Manufaktur yang Terdaftar di BEI. EJurnal Akuntansi Universitas Negeri Padang. Vol. 1, No. 1, pp. 1-13.

Arens, Alvin dan James, K Lobbecke. (2008). Auditting dan Jasa Assurance. Jakarta: Erlangga.

Arsianto, Maydica Rossa dan Rahardjo, Shidiq Nur. (2013). Faktor-faktor yang Mempengaruhi Penerimaan Opini Audit Going Concern. Diponegoro Juournal Of Accounting. Vol. 2, No. 3, pp. 1-8.

Azmi, Zul dan Putra, Jef Rizal. (2014). Opini Audit Going Concern dan Faktor-faktor yang Mempengaruhinya: Studi pada Perusahaan LQ45 di Bursa Efek Indonesia. Jurnal Akuntansi dan Ekonomika. Vol. 4, No. 1, pp. 47-59.

Beawiharta. (2017). Pengusaha: Kondisi Industri Pertambangan Sudah Mulai Membaik. Ditelusuri 16 September 2018 Pukul 20:29. Https://:www.m.merdeka.com.

Bursa Efek Indonesia. (2018). Laporan Keuangan dan Tahunan. Ditelusuri 4 Mei 2018 pukul 2.10. www.idx.co.id.

Dewayanto, Totok. (2011). Analisis Faktor-faktor yang Mempengaruhi Opini Audit Going Concern pada Perusahaan Manufaktur yang Terdaftar di Bursa Efek Indonesia. Fokus ekonomi. Vol. 6, No.1, pp. 81-104.

Gewati, Mikhael. (2016). Industri Tambang Global \& Nasional Ada di Ujung Tanduk?. Ditelusuri 10 September 2018 pukul 21:37. https://ekonomi.kompas.com.

Ghozali, Imam. (2013). Aplikasi Analisis Multivariate dengan program SPSS. Edisi ketujuh. Semarang: Badan Penerbit Universitas Diponegoro.

Hery. (2016). Analisis Laporan Keuangan. Jakarta: PT Grasindo.

Hidayat, Anwar. (2015). Interprestasi Regresi Logistik dengan SPSS. Ditelusuri 11 Agustus 2018 pukul 20:21. https://www.statistikian.com

Ikatan Akuntan Publik Indonesia. (2011). SA Seksi 341: Pertimbangan Auditor atas Kemampuan Entitas dalam Mempertahankan Kelangsungan Hidupnya. Jakarta: Ikatan Akuntan Indonesia. Ditelusuri 11 Agustus 2018 pukul 13:34. https://alengwee.files.wordpress.com/2011/10/sa-seksi-341.pdf

Ikatan Akuntan Publik Indonesia. (2011). Standar Profesional Akuntan Publik. Jakarta: Salemba Empat.

Ikatan Akuntan Indonesia. (2015). Pernyataan Standar Akuntansi Keuangan. Jakarta: Ikatan Akuntan Indonesia.

Junaidi, Jogiyanto dan Hartono. (2010). Faktor Non Keuangan pada Opini Going Concern. Simposium Nasional Akuntansi 13 Purwokerto.

Kartika, Andi. (2012). Pengaruh Kondisi Keuangan dan Non Keuangan terhadap Penerimaan Opini Going Concern pada Perusahaan Manufaktur di BEI. Dinamika keuangan dan perbankan. Vol. 1, No. 1, pp. 25-40. 
Kristiana, Ira. (2012). Pengaruh Ukuran Perusahaan, Profitabilitas, Likuiditas, Pertumbuhan Perusahaan terhadap Opini Audit Going Concern pada Perusahaan Manufaktur yang terdaftar di Bursa Efek Indonesia. Berkah Ilmiah Mahasiswa Akuntansi. Vol. 1, No. 1, pp. 47-51.

Khamidah, Nining Nur dan Ardini, Lilis. (2017). Faktor-faktor yang Mempengaruhi Penerimaan Opini Audit Going Concern. Jurnal Ilmu dan Riset Akuntansi. Vol. 6, No. 5, pp. 1796-1813.

Murdijaningsih, Tjahjani dan Wijaya, Minadi. (2011). Analisis Faktor yang Berpengaruh pada Opini Going Concern : Studi Empiris pada Perusahaan LQ45 yang Listing di IDX). Sustainable Competitive Advantage. Vol. 7, pp. 359-370.

Nariman, Augustpaosa. (2017). Pengaruh Faktor-faktor Perusahaan, Prediksi Kebangkrutan dan Reputasi Auditor terhadap Penerimaan Opini Audit Going Concern. Jurnal Muara Ilmu Ekonomi dan Bisnis. Vol. 1, No. 2, pp. 33-45.

Nursasi, Enggar dan Maria, Evi. (2015). Pengaruh Audit Tenure, Opinion Shopping, Leverage dan Pertumbuhan Perusahaan terhadap Penerimaan Opini Audit Going Concern pada Perusahaan Perbankan dan Pembiayaan yang Go Public di Bursa Efek Indonesia. Jurnal JIBEKA. Vol.9, No. 1, pp. 37-43.

Putra, Danang Anugrah., Anwar, Syaiful Hidayat., dan Nur Thoufan. (2016). Pengaruh Pertumbuhan Perusahaan, Kondisi Keuangan Perusahaan dan Opini Audit Tahun Sebelumnya terhadap Opini Audit Going Concern. Jurnal Reviu Akuntansi dan Keuangan. Vol. 6, No.1, pp. 857-864.

PricewatehouseCoopers. (2016). Tahun 2015 sebagai Tahun Terburuk bagi Sektor Pertambangan. Ditelusuri 16 September 2018 Pukul 20:29. https://www.pwc.com.

Rakatenda, Gusti Ngurah dan Putra, I Wayan. (2016). Opini Audit Going Concern dan Faktor-faktor yang Mempengaruhinya. E-Jurnal Akuntansi Universitas Udayana. Vol. 16, No. 2, pp.1347-1375.

Ramadhani, Karina. (2016). Variabel-variabel yang Mempengaruhi Penerimaan Opini Audit Going Concern pada Perusahaan LQ45 yang Terdaftar di BEI Tahun 2013-2014. Jurnal Riset Mahasiswa Akuntansi. Vol. 2, No. 2, pp. 1-13.

Sari, Dewi Ratna dan Wahyuni, Sri. (2014). Pengaruh Kualitas Audit, Pertumbuhan Perusahaan, Likuiditas dan Solvabilitas terhadap Opini Audit Going Concern pada Perusahaan Manufaktur yang terdaftar di BEI Periode 2011-2013. Kompartemen. Vol. 12, No.1, pp. 69-80.

Sarwono, Jonathan. (2016). Prosedur-prosedur Analisis Populer Aplikasi Riset Skripsi dan Tesis dengan Eviews. Yogyakarta: Gava Media.

Setiawan, Feri dan Suryono, Bambang. (2015). Pengaruh Pertumbuhan Perusahaan, Profitabilitas, Likuiditas dan Leverage terhadap Opini Audit Going Concern. Jurnal Ilmu dan Riset Akuntansi. Vol. 4, No. 3, pp. 1-15. 
Setyarno, Eko Budi, Januarti, Indira dan Faisal. (2006). Pengaruh Kualitas Audit, Kondisi Keuangan Perusahaan, Opini Audit Tahun Sebelumnya, Pertumbuhan Perusahaan Terhadap Opini Audit Going Concern. Simposium Nasional Akuntansi. Vol. 9, pp.1-25.

Siregar, Baldric dan Rahman, Abdul. (2012). Kecenderungan Penerimaan Opini Audit Going Concern: Studi Empiris di Bursa Efek Indonesia. Jurnal Riset Akuntansi dan Keuangan. Vol. 1, No. 2, pp. 91-112.

Sugiyono. (2012). Statistika untuk Penelitian. Bandung: Alfabeta.

Sussanto, Herry dan Aquariza, Nur Mettani. (2012). Analisis Pengaruh Opini Audit Tahun Sebelumnya, Kualitas Auditor, Profitabilitas, Likuiditas dan Solvabilitas terhadap Pemberian Opini Audit Going Concern pada Perusahaan Consumer Goods Industry yang Terdaftar di Bursa Efek Indonesia. UG Jurnal. Vol. 6, No. 12, pp. 14-19.

Sutedja, Christian. (2010). Faktor-faktor yang Berpengaruh terhadap Pemberian Opini Audit Going Concern pada perusahaan Manufaktur. Jurnal Akuntansi Kontemporer. Vol. 2, No. 2, pp. 153-168.

Wulandari, Soliyah. (2014). Analisis Faktor-faktor yang Mempengaruhi Auditor dalam Memberikan Opini Audit Going Concern. E-Jurnal Akuntansi Universitas Udayana. Vol. 6, No. 3, pp. 531-558. 